\title{
Spiroan Entrepots at and Beyond the Western Border of the Tans- Mississippi South
}

Frank Schambach

Arkansas Archaeological Survey

Follow this and additional works at: https://scholarworks.sfasu.edu/ita

Part of the American Material Culture Commons, Archaeological Anthropology Commons, Environmental Studies Commons, Other American Studies Commons, Other Arts and Humanities Commons, Other History of Art, Architecture, and Archaeology Commons, and the United States History Commons

Tell us how this article helped you.

This Article is brought to you for free and open access by the Center for Regional Heritage Research at SFA ScholarWorks. It has been accepted for inclusion in Index of Texas Archaeology: Open Access Gray Literature from the Lone Star State by an authorized editor of SFA ScholarWorks. For more information, please contact cdsscholarworks@sfasu.edu. 


\section{Spiroan Entrepots at and Beyond the Western Border of the Tans-Mississippi South}

\section{Creative Commons License}

\section{(c) (1) (8)}

This work is licensed under a Creative Commons Attribution-NonCommercial 4.0 International License 


\title{
SPIROAN ENTREPOTS AT AND BEYOND THE WESTERN BORDER OF THE TRANS-MISSISSIPPI SOUTH
}

\author{
Frank Schambach \\ Arkansas Archeological Survey
}

Although this paper ${ }^{1}$ is primarily a reinterpretation of the Sanders site in the Red River Valley in northeastern Texas, that reinterpretation will make no sense unless I first outline, very quickly, the new paradigm for the archeology of the Arkansas Valley in eastern Oklahoma and western Arkansas upon which it is based.

For the last five years, as I am sure most of you know, I have been challenging the standard interpretation of the archeology of the Arkansas Valley in eastern Oklahoma and western Arkansas--the Northern Caddoan Area paradigm. I have done this on the grounds that there is no documentary evidence and no archeological evidence for a Caddoan connection of any sort other than trade (Schambach 1988, 1990a, 1990b). In my view the basic biological and cultural ties of this tradition, which I call the Arkansas Valley tradition, were, as Bell (1984:239) has speculated, to the east with peoples of the Central and Lower Mississippi Valley, not to the south with the Caddoan area or to the west with the Wichita. I suspect, as I have said before, that this tradition was a part, at least, of the long lost ancestral Tunican tradition.

A year or so ago I decided that sniping at the old paradigm from the sidelines didn't seem to be having much effect. This was partly because I was operating mainly on intuition and didn't always know as much as I should have about what I was talking about. I decided that the thing to do was read all the literature carefully and try to produce a complete reinterpretation of Arkansas Valley archeology, starting from the premise that it was culturally distinct from the Caddoan area. The result is a long paper which has been circulating in manuscript form since last October. It is now in press, and will be out in April ${ }^{3}$. What I have learned while doing that paper is that the old paradigm, which was never really thought through by anyone--it "just growed "--has been crumbling for more than 20 years. And if you pull together the substantial amount of new thinking and new data that has appeared in the last 20 years and reorganize it according to the premise that the Arkansas Valley was a distinct region ${ }^{4}$, a more plausible culture history emerges--one that lacks the inconsistencies that have been needed to prop up the old one ${ }^{5}$. The highlights of this new culture history can be summarized as follows.

The Mississippi period culture of the Arkansas Valley tradition of eastern Oklahoma--which I call Spiroan culture, following Phillips and Brown (1978:9-10) and Rohrbaugh (1984:272)--has some of the basic characteristics of a Middle Mississippian culture. These include platform mounds, burial mounds, rectangular wattle and daub houses, charnel houses, a small village settlement pattern, shell-tempered pottery, red slipped pottery, storage pits and hoe horticulture. However, there are also certain local variations on these common Mississippian patterns and certain basic traits derived from the Southwest, the Lower Mississippi Valley and the Ozarks that set it off as a distinct regional tradion ${ }^{\text {. Only traded }}$ pots and perhaps a few other traded items, I think, derive from the Caddoan area.

To begin with, I note the recent determination by Bames and Rose (1990:12) that--contrary to expectations generated by the Northern Caddoan area paradigm--the Mississippi period population of the Arkansas Valley was genetically distinct from the Caddoan population of the Ouachita Mountains and the Red River Valley.

Secondly, in recent reviews and compilations of all bioarcheological data from the Trans-Mississippi South and adjacent parts of the Middle and Lower Mississippi Valley, Burnett, Rose and Harmon have assembled clear osteological and dental evidence for different dietary patterns, different food preparation techniques, and different rates and types of infections in the Arkansas Valley as compared to the Caddoan area (Burnett 1988; Harmon and Rose 1989; Burnett 1990).

Surprisingly, and in marked contrast to Caddoan populations in the Ouachitas and farther south, and to Middle Mississippian populations to the east of them in the Mississippi Valley, the Arkansas Valley population never became "maize dependent", not even the population at Spiro (Burnett 1988:220). The botanical and cultural evidence indicates that the Arkansas Valley tradition had a significantly more diverse subsistence system than the Middle Mississippian tradition or even the Caddoan tradition. This system featured hoe horticulture (unknown in the Caddoan area) of most of the plants of the old Woodland period "Cultivated Starchy Seed Complex" of the Ozark highlands plus some corn. There were three Southwestem cultigens: Amaranthus hypochondriacus, Cucurbita mixta and a "non-eastern complex corn" (Fritz 1989:80-86; 1990:9-11). Unlike the Caddoans, the Spiroans processed these foods with stone grinding equipment which caused heavy to severe tooth wear (Bumett 1988a; Schambach 1982:178). The use of bison for food--which would explain the low corn consumption--and for hides and bone tools such as scapula hoes was an important part of the economy by no later than A.D. 1100. This is indicated by the bison bones, bison bone tools, and bison hide processing tools such as diamond shaped beveled knives and uniface end scrapers that appear in significant quantities at Spiro phase and Harlan phase sites such as School Land I and 
II, Norman, Wybark, Sheffield, Tyler-Rose, Cookson and Moore (Schambach 1993:196-199).

In contrast to the Caddoan area, where rates of serious infections were remarkably low during the Mississippi period the Arkansas Valley in eastern Oklahoma was a hotbed of infections, one of which was probably endemic syphilis or some other form of treponemal disease (Harmon and Rose 1989:347-349; Burnett 1988:215-216; Brown 1984:259). The osteitis and osteomyelitis whose incidences indicate serious infections of severe to epidemic proportions in the Spiro phase Horton and Morris site populations, and are more moderately represented in the Spiro site population (Bumett 1988:211214). These are not reported south of the Arkansas Valley, with one exception--which we will come to presently.

The fortified village sites common in the Central Mississippi Valley have not been found. The flat topped mounds of Spiroan culture were not used as foundations for temples or other special purpose structures in the Middle Mississippian (and Middle and Late Caddoan) manner. The sophisticated square to rectangular wattle and daub houses with two or four center posts and extended, wall-trenched entrances that are characteristic of this tradition have not been found in comparably early contexts farther east, and do not occur, except for several exceedingly rare examples in southeastern Oklahoma, in the Caddoan area. This house type probably originated in the Southwest, as Webb (1959:63-64) argued more than thirty years ago, and as Bell suggested in 1971 (in Davis, Wyckoff and Holmes, eds. 1971:82).

Preserved specimens from Spiro and numerous Ozark bluff shelters attest to a coiled basketry tradition that probably came from the Southwest, as Griffin suggested in 1952 (Brown 1976:10-12; Scholtz 1975:30-44; Griffin 1952:102). Coiled basketry impressions on countless bases of flat bottomed, grog-tempered and shelltempered jars indicate that it was lengthy and widespread within the Arkansas Valley tradition. Presumably it did not extend to the Caddoan area, where basketry impressed bases are not found.

Perhaps because coiled baskets that could serve in lieu of pots were available, the ceramic tradition was drastically weaker, in terms of the quantities of pottery in use, than that of either the Central Mississippi Valley or the Caddoan area. Compared to these areas the Arkansas Valley tradition was practically aceramic. The only site that has produced a respectably large ceramic collection by Caddo area standards is Spiro itself. However the WPA collection of 191 pots and 17,552 sherds from Spiro is exceeded by Webb's collection of 195 pots and 19,300 sherds from the Belcher site, a minor Caddo ceremonial

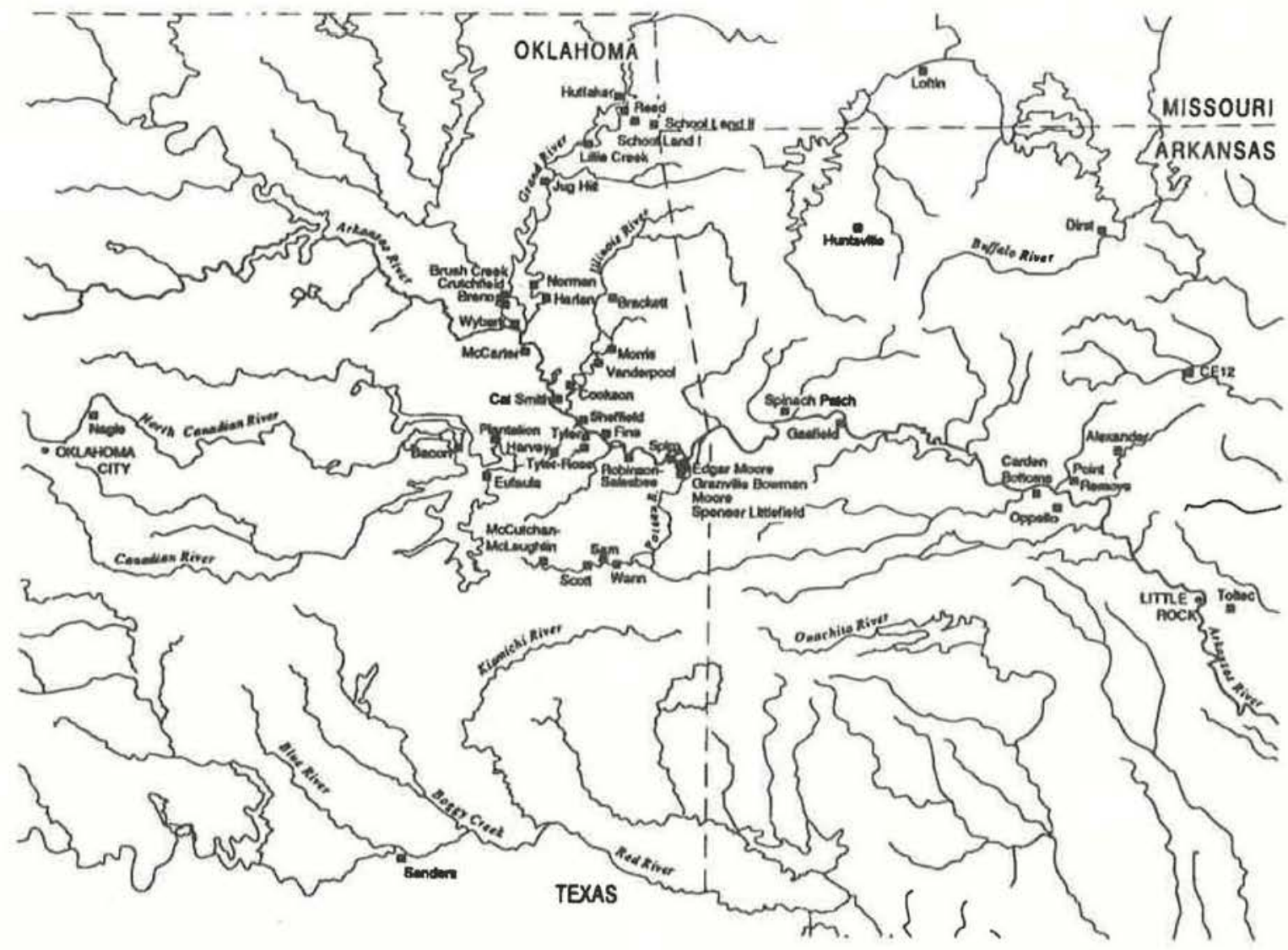

Figure 1. Locations of some of the sites discussed in this paper. 
center on the southern fringe of the Great Bend region in the Red River Valley (Brown 1971:1; Webb 1959:118). According to Wyckoff's tabulations (1980: Tables $106,108,110$ and 112) there were, as of 1980 , only about 24,000 additional sherds on record for all excavated sites in eastern Oklahoma, a total easily matched or exceeded at many Caddo sites such as the Davis site where the WPA excavations produced 96,000 sherds. According to my tabulations and estimates there are, apart from the 191 pots from Spiro, only 341 additional whole pots on record for all excavated sites in the Arkansas Valley in Oklahoma. Compare that, if you will, to the 246 pots that C.B. Moore (1912) found in one small mound at the Foster site, or to the 223 that M. R. Harrington (1920:6263) found in a single small mound at the Washington site.

This was a plain pottery tradition. Decorated sherds and pots are relatively and absolutely scarce. Most assemblages have none. On the other hand, assemblages from the ceremonial centers indicate that there was an unusually high level of interareal trade in decorated pots with the Red River Valley and Ouachita Mountain Caddo, and with Middle Mississippians in the Central Mississippi Valley, that paralleled the more obvious trade, for which Spiro is famous, in items of shell, copper and other exotic materials. It was, more than anything else, the traffic in Caddo pots out of the Red River Valley that fooled us into thinking that the Spiroans themselves were Caddoans. I doubt that anyone would have called Spiro a Caddoan site if it hadn't been for the Caddoan pots.

In any case, in my new paradigm for the Arkansas Valley, I cast the Spiroans as traders and I view the unparalleled deposits of prestige goods at Spiro as hoards of wealth that represent the profits from an equally unparalleled commerce in bison hides and other bison products that was well established by A.D. 1100. From this time on, the Spiroans' main business (literally) was obtaining bison products ${ }^{8}$ from the Southern Plains tribes to the west of them, processing the hides at all those village sites in the Arkansas Valley between the forks of the Arkansas and Spiro itself where hide processing tools are so plentiful, and moving them down river to the fiber, fat and protein poor peoples of the Central Mississippi Valley (Schambach 1993:198-199). They did this in exchange for the Mississippian prestige goods that ultimately found their way into the deposits at Spiro that are so commonly, and so aptly, described as hoards ${ }^{10}$.

At some point, evidently fairly early, the Spiroans broadened the scope of their trade to all kinds of things besides bison products, and they increased their range to the point where they were in contact, at least indirectly, with the Southwest. By A.D. 1300 they had established one entrepot for this long distance trade in the Red River Valley in eastern Texas, and another near present Oklahoma City in the North Canadian River Valley. These western posts, which were certainly not the only ones, were probably complemented by a major Arkansas Valley entrepot somewhere between Fort Smith and Little Rock. My guess is that it was at the Point Remove site, near Morrilton, Arkansas, which is either the easternmost
Arkansas Valley tradition mound group in the Arkansas Valley, or the westernmost Middle Mississippian group.

The Red River Valley entrepot was the Sanders site ${ }^{11}$, located about 150 miles southwest of Spiro in Lamar County, Texas (Figure 1; Krieger 1946:171-182; Wyckoff 1971:85-96; Phillips and Brown 1978:166-167). This puts it--not by accident, I am sure--right on the boundary between the Eastern Woodlands and the Plains (Krieger 1946:172). Sanders was also at the terminus of the most logical route from Spiro to the Red River Valley: up the Poteau Valley from Spiro, then down the Kiamichi Valley to the Red River Valley ${ }^{2}$.

Since some kind of Spiroan connection with Sanders has long been evident because of the engraved and unengraved shell cups and the Craig style engraved gorgets from the graves there, and since Brown (1984:262) has recognized the Sanders phase as a "regional variant" of the Spiro phase, there is no need for me to argue for a strong Spiro connection. What is at issue is the nature of that connection and the status of Krieger's Sanders "focus".

The key fact here is that the Sanders focus was one of the many fictions born of Krieger's concept of the "Gibson-Fulton transition" and his supporting dictum that shell-tempered pottery in the Caddoan area had to be late prehistoric or historic. Now that concept has crumbled in the face of radiometric evidence, it has become apparent that Krieger was unjustified in making the mortuary assemblage from Sanders the basis of his Gibson aspect Sanders focus, thus creating a cultural unit with a trait list that, he was forced to admit, "... may seem quite ethereal" (Krieger 1946:203). It is now clear that the midden assemblage which he relegated to a much later Fulton aspect occupation because of what he considered late "Plains" traits such as plain shell-tempered pottery, bison scapula hoes, end scrapers, and diamond shaped beveled knives could easily have been, and probably was, mostly occupation debris laid down by the same Spiro phase people responsible for the graves. In fact, the complete assemblage from Sanders can plausibly be viewed as a site unit intrusion of Spiroans from the Arkansas Valley. There is nothing in the general run of artifacts in the Sanders assemblage that cannot be found on Harlan and Spiro phases sites in eastern Oklahoma. Conversely, there is much that cannot be found downriver from Sanders a hundred miles or so in the Caddo country: things like bison bone hoes, stone hoes, stone seed grinding equipment, end scrapers, diamond shaped beveled knives, bone beamers, bone fish hooks, shell-tempered Woodward Plain pottery and Sanders Plain pottery.

Once we rid ourselves of the notion that Sanders Plain pottery, the marker type for the so-called Sanders focus, is a Caddo type because it is so listed in The Handbook of Texas Archeology there is no reason to think of Sanders as anything but an intrusion. Sanders Plain is not a Caddoan type or an eastern Texas type. It is an Arkansas Valley variety of the Middle Mississippian type 
Old Town Red, the basic mortuary and ceremonial type of the Parkin and Quapaw phases of eastern Arkansas (Brown 1971:164-169; Phillips 1970:145). Krieger's (1946:186-190) perfunctory and overly loose definition of this type is based on no more than 21 Old Town Red bowls found in the graves of peripatetic Spiroan traders who brought them down from Spiro along with other more obvious imports such as negative painted pottery, Mississippi Valley "bean pots," and limestone-tempered Monks Mound Red pottery (Krieger 1946:176-183). All of this mortuary pottery got to Sanders just the way the four conch shell cups, the twenty-one shell gorgets, including "Craig School" specimens that "must have come from the Arkansas Valley" (Brown 1983:150) and the 5,500 conch shell beads got there: on the backs ${ }^{14}$ of traders walking up the Poteau Valley and down the Kiamichi Valley.

This interpretation of Sanders as a site unit intrusion is supported by two recent bianthropological studies in which the Sanders site skeletal population unexpectedly emerged as "markedly different" in several ways from Caddoan skeletal populations in the Red River Valley (Burnett 1990:393-399). These studies indicate that the people themselves were Spiroan immigrants from the Arkansas Valley. In an M.A. thesis project that involved comparing the ostensibly Caddoan Sanders site skeletons with the Texarkana phase Caddoan skeletons from the Hatchel-Mitchell site 120 miles down the Red River, Dow (1987) discovered that the two populations were genetically different. Having, of course, no inkling that this might be due to the Sanders people being Spiroans from the Arkansas Valley, she attributed this to the possibility that they were interbreeding with Plains people (Dow 1987:111).

Another study by Barbara Jackson (unpublished; raw data summarized in Burnett: 1990:393-398) uncovered two additional peculiarities of the Sanders population which Burnett (1990) finds impossible to explain within the conceptual framework we archeologists have provided. First, the infection rate of the adult population at Sanders (33.3\%) is "dramatically" high compared to other populations in the Red River Valley. In the case of two of the six adults examined, the lesions in evidence are those of osteitis and osteomyelitis, neither of which has been identified in early Caddoan populations in the Red River Valley or elsewhere in the Caddoan area. Therefore they seem to point straight to the Spiro phase skeletal populations from the Spiro, Morris and Horton sites in Arkansas Valley. There, as we have seen, the incidence of osteitis and osteomyelitis is unusually high, and the osteitis is thought to indicate a high incidence of endemic syphilis or some other treponemal infection (Brown 1984:259; Burnett 1988: 212-214).

Secondly, the infections indicated by these lesions had an abnormal distribution within the population. While the adult infection rate was comparatively high, the nine children studied were infection free. Burnett (1990:397), notes that this is a "confusing picture"... "that deserves further testing." The hypothesis to be tested here, I suggest, is that the adults, who were immigrant traders, acquired their lesions as children (endemic syphilis being a contagious disease of childhood; Hackett 1963:10) in their infection ridden Arkansas Valley homeland. Their children, however, were born at the Red River Valley trading post, far from the Spiroan population center that harbored the pathogens responsible for osteitis and osteomyelitis.

What were Spiroan traders doing at the Sanders site ${ }^{15}$ ? There is good circumstantial and distributional evidence that from this location they were in contact with Southern Plains bison hunters, with the ancestral Kadohadacho and other eastern Caddoan groups in the Red River Valley, with the ancestral Hasinai and other western Caddoans in eastern Texas, and (probably indirectly through a Pueblo-Southern Plains trade network; Creel: 1991) with Puebloans in eastern New Mexico.

A trading post at this location would have given the Spiroans access to whatever bison products and Puebloan goods the Pueblo-Southern Plains trade network might have been moving down the Washita River and the Red River to the Caddo area. Their suppliers would have been people of the Washita River phase, probably the ancestral Wichita, who occupied the Washita and the Canadian River drainages of west central Oklahoma from at least A.D. 1150 through A.D. 1400 (Bell 1984b:323). The Washita River phase artifact inventory includes numerous hide processing tools: bone beamers, bone "hide grainers", diamond shaped beveled knives, and end scrapers (Bell 1980:65; 1984b: Figures 14.3-14.5). The latter two are considered diagnostic of participation in the Southern Plains hide trade (Creel 1991). It also includes various items indicative of contact with Southeasterners: a conch shell omament, a fragment of a decorated stone ear spool, and occasional specimens of Southeastern pottery in the form of sherds and whole vessels. The most notable of the latter is a human effigy generally considered an import from the Tennessee-Cumberland area (Bell 1984:322) ${ }^{16}$. Furthermore, this inventory is such that evidence that Washita River people frequented the Sanders site could easily reside in the still unstudied collections from the middens (which Krieger did, after all, attribute to an occupation by Plains people. He may have been partly right about the attribution but wrong about the time). The best evidence that something of this nature did go on at Sanders is a single smudged black Puebloan sherd that probably came from southeastern New Mexico (Krieger 1946:197,208).

The evidence for trade downriver to the Caddo country is stronger, although I suspect that the trade upriver was more important. A Haley Engraved bottle (Krieger 1946: Fig. 15) shows the Spiroans were in touch directly or indirectly with Haley phase people about 150 miles away in the Great Bend region of southwestern Arkansas (Schambach 1982b). Hones of white Catahoula sandstone came from farther south in northwestern Louisiana (Krieger 1946:203). Some 150 sherds of shell-tempered Nash Neck Banded jars suggest contacts with Caddoan salt producers in the Little River region of southwestern Arkansas and hint that one of the commodities moving upriver was salt (Krieger 1946:197). 
The rare Mississippi Valley prestige goods found at Caddoan sites in the Red River Valley such as the Spiro-related conch shell cups and gorgets (Phillips and Brown 1978:165-168) found at the Rhoden site in McCurtain County, Oklahoma, the Bowman site in Little River County, Arkansas, and the Belcher site in Caddo Parish, Louisiana, and the plain shell cups found at the Foster and Friday sites (Moore 1912: Figs. 76,77,86) probably passed through the Sanders site entrepot on their way down from Spiro. So did the painted bottle from the Haley site which Moore (1912:550; Plate XXXVIII) considered "an import from Southeastern Missouri". The previously inexplicable population of Central Mississippi Valley bird effigy bowls, many of them of the "tail rider" variety, that centers in Lafayette and Miller counties in extreme southwestern Arkansas and in Cherokee, Harrison, Titus and Red River counties in northeastern Texas (Suhm and Jelks 1962:47-49; Plate 24) certainly owes its existence to the Sanders entrepot. These vessels occur in a tight cluster, the northwestern edge of which is located precisely south of the confluence of the Kiamichi River with the Red River. Distributional evidence doesn't come much better than that.

Fifteen sherds "definitely of Titus Focus types" point to contacts with northeastern Texas Caddoans in the Sulphur River drainage (Krieger 1946:197). To Krieger's surprise, there were also "at least 15 sherds of Frankston Focus types"; these indicate contacts with ancestral Hasinai Caddo people living 100 to 150 miles south of Sanders in the Neches, Angelina and upper Sabine valleys (Krieger 1946:197).

What kinds of goods were being accumulated at Sanders for portage up the Kiamichi and Poteau Valleys to the Arkansas Valley? Judging from traded specimens found at or near Spiro, (Brown 1976; 1983; 1984:245262; Rohrbaugh 1982:538) these probably included cotton cloth ${ }^{17}$, woven bison hair skirts and bags, baskets, artifacts of Alibates flint and Red River jasper, and long stemmed Caddoan tobacco pipes of the Red River type.

Furthermore, Brown (1983:144, Table 4) recognizes that pots of the Red River Valley types Haley Engraved, Handy Engraved, and Avery Engraved are probably trade items at Spiro, so they can be added to this list. So should every vessel of the early Caddoan types Crockett Curvilinear Incised, Pennington Punctated Incised, Holly Fine Engraved, Hickory Engraved, and (the misnamed) Spiro Engraved whose presence--in extremely small numbers at an equally small number of Arkansas Valley sites--has done so much to cloud our thinking about the nature of the Arkansas Valley tradition. There are, after all, only 18 vessels and 74 sherds of Crockett Curvilinear Incised in the Spiro collections that Brown studied, and only 22 vessels and 108 sherds of Spiro Engraved (Brown 1971:82,109). The next largest collection of these types is from the Harlan site where Bell (1972:243-247) found seven Crockett Curvilinear Incised vessels, five Pennington Punctated Incised, five Spiro Engraved, four Hickory Fine Engraved, one Holly Fine Engraved and almost no sherds. Outside of these two collections, vessels of these types are scarcer than hen's teeth. On the basis of what I have learned in the past year about the real nature of the Arkansas Valley ceramic tradition, I would bet that the total number of vessels of these five types (including vessels represented by accurately identified sherds) that could be confirmed from all Arkansas Valley tradition collections would be in the neighborhood of 100 to 150 . That is not too many for a few decades of overland trade out of the Red River Valley. Not for traders who could move 3,000 to 4,000 conch shell cups (Brown 1975:151) up the Arkansas River to Spiro, presumably from an entrepot about 150 upriver miles away at Point Remove.

Finally there is some tantalizing circumstantial evidence that when Spiroan traders began acting as intermediaries between the large population centers of the Mississippi Valley and the Southwest they may have bought themselves and everyone else the kind of epidemiological trouble that often arises when large populations that have been well separated geographically and culturally are suddenly linked by traders or explorers.

In this case infectious diseases, as well as goods, may have moved, with serious if not disastrous results, from the Southwest to the Arkansas Valley, and then to the Mississippi Valley. As I understand the bioanthropological literature, which is not as clear as it might be on this point, the childhood osteitis and osteomyelitis that account for the epidemic level infection rates (67 to $85 \%$ ) in the Spiroan populations from the Morris and Horton sites in eastern Oklahoma (Burnett 1988:212-214) are rare to absent in populations of all periods east of Spiro prior to the late Mississippi period, at which time they appeared (as part of a "dramatic rise" in infection rates to $90 \%$, from $35.3 \%$ in the Middle Mississippi period) as adult level infections in northeastern Arkansas (Burnett 1988:150-151; Rose et.al. 1984: 418). This Late Mississippi period increase in infection rates is presently attributed to population growth and the appearance of large towns and "widespread trade" (Bumett 1988: 150151; Rose et. al. 1984:418) This is probably quite true, except the trade in question may have been considerably more widespread than we have thought.

The reason for the absence of osteitis in subadult populations in the Southeast may be that it is diagnostic of endemic syphilis, a treponemal disease of childhood that is so strongly associated with arid regions that Hackett (1963: 8) has remarked that it should be called "treponaridosis". My biomedically untutored evaluation of the situation in eastern Oklahoma (where endemic syphilis has been diagnosed; see Brown 1984:259) is that area was much too humid for endemic syphilis to have developed locally, and that the high frequency and severity of the disease as it is manifested in the skeletons from the Morris and Horton sites bespeak a recent introduction from the Southwest. The vector would have been children who were brought from there, probably for adoption or for use as slaves, neither practice being unheard of in North America in the post Colombian era ${ }^{8}$. 
It would appear that in the course of the resulting epidemic among the children in the Spiro area this disease and whatever disease was responsible for the osteomyelitis spread, in the classic manner, to the immunologically unprotected adult population, probably producing what Burnett (1988:151) describes as "chronic and extremely debilitating infections."

The broader epidemiological question, should there be any truth in the foregoing, is: were these and perhaps other diseases of Southwestern origin involved in the collapse of Spiro and other major Mississippian centers about A.D. 1450, and in the Mississippian population collapse that most bioanthropologists believe was underway before the De Soto entrada? Did Spiroan traders bring down Mississippian culture by introducing diseases from the Southwest?

If the Spiroans were the traders I make them out to be, there should be other Spiroan entrepots along the Canadian and Arkansas Rivers in the plains country of central Oklahoma. But if they are like the Sanders site they will be hard to identify from surface debris or midden excavations alone. The evidence that brought the Sanders site to our attention was all in the graves. Had they not been found, the Sanders site would today be passing unnoticed as a Plains village component. So any Plains Village site in the Arkansas and Canadian drainages could suddenly emerge as another Spiroan entrepot.

One possibility is the Nagle site, on the North Canadian River near Oklahoma City (Shaeffer 1957). There, in an accidentally discovered cemetery, four graves that were professionally excavated after machinery destroyed 12 others. All contained-shades of Sanders--locally exotic artifacts, probably out of the Spiro phase of the Arkansas Valley tradition (Shaeffer 1957:93-97). There were two Woodward Plain jars, one "marine conch shell" bead "identical in shape with necklace beads from Spiro Mound", and five triangular, side notched arrowpoints that Griffin (1961:30) calls "similar to the Cahokia side-notched forms". Two copper covered, sandstone ear spools were found by a visitor in a trenched area between the four graves that were salvaged. According to Shaeffer (1957) and Griffin (1961), both are Baerreis's type $\mathrm{A}$, one of the types he considered diagnostic of the Spiro "focus" (Baerreis 1957:34), now the Spiro phase.

Like the Sanders site population, the Nagle site skeletal population exhibits bone lesions suggesting "a totally different series of health problems" than those exhibited by skeletal populations from nearby Central Plains sites (Owsley and Jantz 1989:140). The 20 skeletons from Nagle exhibited "a severe mortality profile, associated with pronounced evidence of bone disease" indicative of "dietary deficiencies, possibly scurvy and a syphilis-like bone disease" (Owsley 1989:131; Brues 1957) ${ }^{20}$.

Brues (1959:66) linked this population to the Morris and Horton site populations of eastern Oklahoma on the basis of similar paleopathology, particularly the evidence of a syphilis-like bone disease and on the basis of the frontal-occipital cranial deformation exhibited by skulls from all three sites.

The latter is also in evidence at the Sanders site, as Brues pointed out in her Nagle site report, and--unknown to her in 1957-59--at Spiro itself (Brues 1957:104; Brown 1984:159). The cranial deformation reported at Nagle, like the osteological evidence of pathology, is not reported for other Central Oklahoma sites. In fact, Bell (1984:309) states: "There is no suggestion of any skull deformation" in the skeletons, also studied by Brues, of the Washita River "focus" who frequented the Oklahoma city area between A.D. 1000 and A.D. 1450. Thus the artifacts and the skeletal evidence from Nagle, like those from Sanders, indicate an occupation by Spiroan intruders from the Arkansas Valley who were, I suggest, operating a wide ranging trading enterprise ${ }^{21}$, probably at great epidemiological cost to themselves and everyone they contacted.

\section{ACKNOWLEDGEMENTS}

I thank Leonard Blake for giving me an introduction to the scientific literature on Osage orange and I thank Cathy Cande, Maynard Cliff and Dan Morse for information pertaining to various aspects of this paper. However none of these people has seen or endorsed the finished product.

\section{REFERENCES}

Albert, Lois E.

1992 The Norman Site (34W62), Wagoner County, Oklahoma. Paper presented at the 33rd Annual Caddo Conference, Stephen F. Austin State University, Nacogdoches.

Baerreis, David A.

1957 The Southern Cult and the Spiro Ceremonial Complex. Bulletin of the Oklahoma Anthropological Society 5:23-28.

Barnes, James E. and Jerome C. Rose

1990 Dental Morphological Variants and Kinship Among Prehistoric Caddo. Paper presented at the 55th Annual Meeting of the Society for American Archaeology, Las Vegas.

Baugh, Timothy G.

1991 Ecology and Exchange: The Dynamics of Plains-Pueblo Interaction. Farmers, Hunters, and Colonists: Interaction between the Southwest and the Southern Plains, edited by Katherine B. Spielmann, pp. 107-127. University of Arizona Press, Tucson. 
Bell, Robert E.

1972 The Harlan Site, Ck-6. A Prehistoric Mound Center in Cherokee County, Eastern Oklahoma. Oklahoma Anthropological Society Memoir 2.

1980 Oklahoma Indian Artifacts. Contributions from the Stovall Museum 4, The University of Oklahoma, Norman.

1984a Arkansas Valley Caddoan: The Harlan Phase. In Prehistory of Oklahoma, edited by Robert E. Bell, pp. 221-240. Academic Press, New York.

1984b The Plains Villagers: The Washita River. In Prehistory of Oklahoma, edited by Robert E. Bell, pp. 307-324. Academic Press, New York.

Briscoe, James

1977 The Plantation Site (Mi63), an Early Caddoan Settlement in Eastern Oklahoma. Oklahoma Highway Archeological Survey, Papers in Highway Archaeology 3. Oklahoma City.

Brown, James A.

1966a Spiro Studies, Volume 1. Description of the Mound Group. Stovall Museum of Science and History and The University of Oklahoma Research Institute, Norman.

1966b Spiro Studies, Volume 2. The Graves and Their Contexts. Stovall Museum of Science and History and The University Of Oklahoma Research Institute, Norman.

1971 Spiro Studies, Volume 3. Pottery Vessels. Stovall Museum of Science and History and The University of Oklahoma Research Institute, Norman.

1975 Spiro Art and Its Mortuary Contexts. In Death and the Afterlife in Pre-Colombian America, edited by Elizabeth P. Benson, pp. 1-32. Dumbarton Oaks Research Library and Collections, Washington, D.C.

1976 Spiro Studies, Volume 4. The Artifacts. Second Part of the Third Annual Report of Caddoan Archaeology-Spiro Focus Research. Stovall Museum of Science and History and The University of Oklahoma Research Institute, Norman.

1983 Spiro Exchange Connection Revealed by Sources of Imported Raw Materials. In Southeastern Natives and Their Pasts: A Collection of Papers Honoring Dr. Robert E. Bell, edited by Don G. Wyckoff and Jack L. Hofman. Oklahoma Archeological Survey Studies in Oklahoma's Past 11:129-162.

1984 Arkansas Valley Caddoan: The Spiro Phase. Prehistory of Oklahoma, edited by Robert E. Bell, pp. 241-263. Academic Press, New York. 1984b Prehistoric Southern Ozark Marginality: A Myth Exposed. Missouri Archaeological Society, Special Publication 6. Columbia.

Brown, James A., Robert E. Bell and Don G. Wyckoff 1978 Caddoan Settlement Patterns in the Arkansas River Drainage. In Mississippian Settlement Patterns, edited by Bruce D. Smith, pp. 169200. Academic Press, New York.

Brues, Alice

1957 Skeletal Material from the Nagle Site. Bulletin of the Oklahoma Anthropological Society 5:101-106.

1958 Skeletal Material from the Horton Site. Bulletin of the Oklahoma Anthropological Society 6:27-32.

1965 Unpublished and untitled 1965 manuscript on the skeletons from the Craig Mound at Spiro. Read and cited with permission of the author.

Burnett, Barbara A.

1988a The Biological Synthesis. In Human Adaptation in the Ozark and Ouachita Mountains, edited by George Sabo III, Ann M. Early, Jerome C. Rose, Barbara A. Burnett, Louis Vogel, Jr. and James P. Harcourt, Arkansas Archeological Survey Research Series 31:193-220. Fayetteville.

1988 Standridge Bioarcheology and the Middle Ouachita Caddo. In Standridge: Caddoan Settlement in a Mountain Environment, edited by Ann M. Early, with Barbara A. Burnett and Daniel Wolfman. Arkansas Archeological Survey Research Series 29:143-152. Fayetteville.

1990 The Bioarcheological Synthesis of the Gulf Coastal Plain Study Area. In The Archeology and Bio-archeology of the Gulf Coastal Plain, Vol. 2, by Dee Ann Story, Janice A. Guy, Barbara A. Burnett, Martha Doty Freeman, Jerome C. Rose, D. Gentry Steele, Ben W. Olive, and Karl J. Reinhard. Arkansas Archeological Survey Research Series 38:385-508. Fayetteville.

Creel, Darrell

1991 Bison Hides in Late Prehistoric Exchange in the Southern Plains. American Antiquity 56(1):40-49.

Davis, Hester A., Don G. Wyckoff and Mary A. Holmes 1971 Proceedings of the Seventh Caddo Conference. Oklahoma Archeological Survey, Occasional Publication 1, The University of Oklahoma. Norman. 
Dow, Laura Ann Brantly

1987 The Genetic Affinities and Adaptive Success of Three Groups of Late Prehistoric Amerindians from Texas. Unpublished Master's thesis, The University of Texas, Austin.

Duffield, Lathel F.

1969 The Vertebrate Faunal Remains from the School Land I and School Land II Sites, Delaware County, Oklahoma. Oklahoma Anthropological Society Bulletin 18:47-65.

Early, Ann M.

1988 Standridge: Caddoan Settlement in a Mountain Environment. Arkansas Archeological Survey Research Series 29. Fayetteville.

Finkelstein, Joe J.

1940 The Norman Site Excavations Near Wagoner, Oklahoma. The Oklahoma Prehistorian 3(3): 12-15.

Flannery, Kent V.

1968 The Olmec and the Valley of Oaxaca: A Model for Inter-regional Interaction in Formative Times. In Dumbarton Oaks Conference on the Olmec, edited by Elizabeth Benson, pp.79117. Dumbarton Oaks Research Library and Collection, Washington, D.C.

Freeman, Joan E. and A. Dewey Buck, Jr.

1959 Woodward Plain and Neosho Punctate, Two Shell Tempered Pottery Types of Northeastern Oklahoma. Bulletin of the Oklahoma Anthropological Society 8:3-16.

Fritz, Gayle J.

1989 Evidence of Plant Use from Copple Mound at the Spiro Site. In Contributions to Spiro Archeology: Mound Excavations and Regional Perspectives, edited by J. Daniel Rogers, Don G. Wyckoff and Dennis A. Peterson, Oklahoma Archeological Survey, Studies in Oklahoma's Past 16:65-87, Norman.

1990 Agricultural Patterning in the Northern Caddoan Archaeological Region. Paper presented to the 55th Meeting of the Society for American Archaeology, Las Vegas.

Griffin, James B.

1952 An Interpretation of the Place of Spiro in Southeastern Archaeology. In The Spiro Mound, by Henry W. Hamilton. Missouri Archaeologist 14:89-106. Columbia.

1961 Relationships Between the Caddoan Area and the Mississippi Valley. Bulletin of the Texas Archeological Society 31:27-43.

Hackett, C. J.

1963 On the Origin of the Human Treponematoses. Bulletin WHO 29:7-41.
Hamm, Jim

1989 Bows and Arrows of the Native Americans. Lyons and Buford, Publishers, in cooperation with Bois d'Arc Press.

Harmon, Ann M. and Jerome C. Rose

1989 Bioarcheology of the Louisiana and Arkansas Study Area. In Archeology and Bioarcheology of the Lower Mississippi South in Arkansas and Louisiana, by Marvin D. Jeter, Jerome C. Rose, Ishmael Williams, Jr., and Anna M. Harmon. Arkansas Archeological Survey Research Series 37:323-354. Fayetteville.

Harrar, Ellwood S. and J. George Harrar

1962 Guide to Southern Trees, 2nd ed. Dover Publications, Inc., New York.

Harrington, M. R.

1920 Certain Caddo Sites in Arkansas. Museum of the American Indian, Miscellaneous Series 10. Heye Foundation, New York.

Hemmings, E. Thomas

1982 Spirit Lake (3LA83): Test Excavations in a Late Caddo Site on the Red River. In Contributions to the Archeology of the Great Bend Region, edited by Frank F. Schambach and Frank Rackerby. Arkansas Archeological Survey Research Series 22:55-89. Fayetteville.

Kidder, Tristram R.

1993 The Glendora Phase: Protohistoric-Early Historic Dynamics on the Lower Ouachita River. In Archaeology of Eastern North America; Papers in Honor of Stephen Williams, edited by James B. Stoltman. Missouri Department of Archives and History, Archaeological Report 25:320-260.

Krieger, Alex D.

1946 Culture Complexes and Chronology in Northern Texas, with Extensions of Puebloan Datings to the Mississippi Valley. Publication 4640. The University of Texas, Austin.

Kuttruff, Jenna Tedrick

1993 Mississippian Period Status Differentiation Through Textile Analysis: A Caddoan Example. American Antiquity 56:125-145.

Lintz, Christopher

1991 Texas Panhandle-Pueblo Interactions from the Thirteenth Through the Sixteenth Century. In Farmers, Hunters, and Colonists: Interaction Between the Southwest and the Southern Plains, edited by Katherine B. Spielmann, pp. 89-106. University of Arizona Press, Tucson. 
Lopez, David R.

1973 The Wybark Site: A Late Prehistoric Village Complex in the Three Forks Local, Muskogee, Oklahoma. Oklahoma Anthropological Society Bulletin 22:11-126.

Mason, Otis Tufton

1972 North American Indian Bows, Arrows, and Quivers. Carl J. Pugliese, Yonkers.

McClellan, Catherine

1953 The Inland Tlingit. Asia and North America: Trans-Pacific Contacts. Society for American Archeology Memoirs 9:47-52.

Mooney, James

1896 The Caddo and Associated Tribes. Fourteenth Annual Report of the Bureau of American Ethnology for 1892-1893, Part 2:1092-1103.

Moore, C. B.

1912 Some Aboriginal Sites on Red River. Journal of the Academy of Natural Sciences of Philadelphia 14:482-655.

Newell, H. Perry and Alex D. Krieger

1949 The George C. Davis Site, Cherokee County, Texas. Memoir No. 5, Society for American Archaeology, Washington, D.C.

O'Brien, Patricia J.

1993 Steed-Kisker: The Western Periphery of the Mississippian Tradition. Midcontinental Journal of Archaeology 18(1):61-96.

Orr, Kenneth Gordon

1946 The Archaeological Situation at Spiro, Oklahoma: A Preliminary Report. American Antiquity 4:228-256.

Owsley, Douglas W.

1989 The History of Bioarcheological Research in the Southern Great Plains. In From Clovis to Comanchero: Archeological Overview of the Southern Great Plains, by Jack L. Hoffman, Robert L. Brooks, Joe S. Hays, Douglas W. Owsley, Richard L. Jantz, Murray K. Marks, and Mary H. Manhein. Arkansas Archeological Survey Research Series 35:123-136. Fayetteville.

Owsley, Douglas and Richard L. Jantz

1989 A Systematic Approach to the Skeletal Biology of Southern Plains. In From Clovis to Comanchero: Archeological Overview of the Southern Great Plains, by Joe S. Hays, Douglas W. Owsley, Richard L. Jantz, Murray K. Marks, and Mary H. Manhein. Arkansas Archeological Survey Research Series 35:137-156. Fayetteville.
Peattie, Donald Culross

1953 A Natural History of Western Trees. Houghton-Mifflin Company, Boston.

Perttula, Timothy $\mathrm{K}$.

1992 The Caddo Nation: Archaeological and Ethnohistoric Perspectives. University of Texas Press, Austin.

Peterson, Dennis A.

1989 Interpreting the Copple Mound Findings. In Contributions to Spiro Archeology: Mound Excavations and Regional Perspectives. Edited by J. Daniel Rogers, Don G. Wyckoff and Dennis A. Peterson. Oklahoma Archeological Survey, Studies in Oklahoma's Past 16:27-41. Norman.

Petrides, George A.

1972 A Field Guide to Trees and Shrubs, 2nd ed. The Peterson Field Guide Series, Houghton Mifflin Company, Boston.

Phillips, Philip

1970 Archaeological Survey in the Lower Yazoo Basin, Mississippi, 1949-1955. Papers of the Peabody Museum of Archaeology and Ethnology 60. Harvard University, Cambridge.

Phillips, Philip and James A. Brown

1978 Pre-Colombian Shell Engravings from the Craig Mound at Spiro, Oklahoma. Part I, Paperback Edition. Peabody Museum of Archaeology and Ethnology, Harvard University, Cambridge.

Phillips, Philip, James A. Ford and James B. Griffin

1951 Archaeological Survey in the Lower Mississippi Alluvial Valley, 1940-1947. Papers of the Peabody Museum of American Archeology and Ethnology, No. 25. Harvard University, Cambridge.

Pillaert, E. Elizabeth

1963 The McLemore Site of the Washita River Focus. Bulletin of the Oklahoma Anthropological Society 11:1-114.

Pope, Saxton T.

1962 Bows and Arrows. University of California Press, Berkeley.

Preston, Richard, Jr.

1989 North American Trees, Exclusive of Mexico and Tropical Florida, 4th ed. Iowa State University Press, Ames.

Prewitt, Terry

1974 Regional Interaction Networks and the Caddoan Area. Papers in Anthropology, Department of Anthropology, The University of Oklahoma. 15:73-101. Norman. 
Robbins, Wilfred William, John Peabody Harrington and

Barbara Freire-Marreco

1916 Ethnobotany of the Tewa. Smithsonian Institution Bureau of American Ethnology, Bulletin No. 55.

Rogers, J. Daniel

1989 Settlement Contexts for Shifting Authority in the Arkansas Basin. In Contributions to Spiro Archeology: Mound Excavations and Regional Perspectives, edited by J. Daniel Rogers, Don G. Wyckoff and Dennis A. Peterson. Oklahoma Archeological Survey, Studies in Oklahoma's Past 16:159-176.

1991 Regional Prehistory and the Spiro Phase. Southeastern Archeology 10:63-68.

Rohrbaugh, Charles L.

1982 Spiro and Fort Coffee Phases: Changing Cultural Complexes of the Caddoan Area. Ph.D. dissertation, Department of Anthropology, University of Wisconsin, Madison.

1984 Arkansas Valley Caddoan: Fort Coffee and Neosho Foci. In Prehistory of Oklahoma, edited by Robert E. Bell, pp. 265-285. Academic Press, New York.

Rose, Jerome C., Barbara A. Burnett, Mark W. Blaeuer and Michael S. Nassaney

1984 Paleopathology and the Origins of Maize Agriculture in the Lower Mississippi Valley and Caddoan Culture Areas. In Paleopathology and the Origins of Agriculture, edited by Mark N. Cohen and George J. Armelagos, pp. 393-424. Academic Press, New York.

Schambach, Frank F.

1982 An Outline of Fourche Maline Culture in Southwest Arkansas. In Arkansas Archeology in Review, edited by Neal J. Trubowitz and Marvin D. Jeter. Arkansas Archeological Survey Research Series 15:132-197. Fayetteville.

1982b The Archeology of the Great Bend Region in Arkansas. In Contributions to the Archeology of the Great Bend Region, edited by Frank F. Schambach and Frank Rackerby. Arkansas Archeological Survey Research Series 22:111. Fayetteville.

1990a The Place of Spiro in Southeastern Prehistory: Is It Caddoan or Mississippian? Southeastern Archaeology 9(1):67-69.

1990b The Place of the Spiro Site in Southeastern Prehistory: A Reinterpretation. Paper presented at the 48th Annual Southeastern Archaeological Conference, Mobile, Alabama.

1990 The "Northern Caddo Area" Was Not Caddoan. Caddoan Archeology 1(4):1-6.
1991 Coles Creek Culture and the Trans-Mississippi South. Caddoan Archeology 2(3):2-8.

1993 Some New Interpretations of Spiroan Culture History. Archaeology of Eastern North America: Papers in Honor of Stephen Williams. Mississippi Department of Archives and History, Archaeological Report 25:187230.

Scholtz, Sandra

1975 Prehistoric Plies: A Structural and Comparative Analysis of Cordage, Netting, Basketry and Fabric from Ozark Bluff Shelters. Arkansas Archeological Survey Research Series 9. Fayetteville.

Shaeffer, James B.

1957 The Nagle Site, Ok-4. Bulletin of the Oklahoma Anthropological Society 5:93-99. Oklahoma City.

Spielmann, Katherine Ann

1986 Interdependence Among Egalitarian Societies. Journal of Anthropological Research 5:279-313.

1991 a Coercion or Cooperation? Plains-Pueblo Interaction in the Protohistoric Period. In Farmers, Hunters, and Colonists: Interaction between the Southwest and the Southern Plains, edited by Katherine B. Spielmann, pp. 36-50. University of Arizona Press, Tucson.

1991b Interaction Among Nonhierarchical Societies. In Farmers, Hunters, and Colonists: Interaction Between the Southwest and the Southern Plains, edited by Katherine B. Spielmann, pp. 1-17. University of Arizona Press, Tucson.

Story, Dee Ann

1991 Some Comments on the Status of Caddoan Archaeology. News and Views, Newsletter of the Department of Archeological Planning and Review, Texas Historical Commission 3:1718.

Suhm, Dee Ann and Edward B. Jelks

1962 Handbook of Texas Archeology: Type Descriptions. Texas Archeological Society, Special Publication 1 and the Texas Memorial Museum, Bulletin 4, Austin.

Swanton, John R.

1942 Source Material on the History and Ethnology of the Caddo Indians. Smithsonian Institution, Bureau of American Ethnology, Bulletin 132. Washington.

Waldorf, D.C.

1985 The Art of Making Primitive Bows and Arrows. Mound Builder Books, Branson. 


\author{
Webb, Clarence H. \\ 1959 The Belcher Mound: A Stratified Caddoan Site \\ in Caddo Parish, Louisiana. Society for \\ American Archaeology Memoir No. 16. \\ Washington, D.C. \\ 1984 Early Caddo Cultures (Caddo I and 2). Slide \\ Set published by Pictures of Record Incor- \\ porated, Weston, Connecticut.
Wilson, Diane
1993 Incidence of Degenerative Joint Disease Among the Sanders Site (41LR2) Population. Paper read at the 35th Caddo Conference, Norman. \\ Wyckoff, Don G. \\ 1970 The Horton Site Revisited, 1967 Excavations \\ at Sq-11, Sequoyah County, Oklahoma. Ok-
}

lahoma Archeological Survey, Studies in Oklahoma's Past 1 . Norman.

1971 The Caddoan Cultural Area: An Archaeological Perspective. Oklahoma Archeological Survey, The University of Oklahoma, Norman.

1980 Caddoan Adoptive Strategies in the Arkansas Basin, Eastern Oklahoma. Ph.D. dissertation, Washington State University, Pullman.

1989 A Synopsis of the 1982 Field Work and Findings. Contributions to Spiro Archeology: Mound Excavations and Regional Perspectives, edited by J. Daniel Rogers, Don G. Wyckoff and Dennis A. Peterson, Oklahoma Archeological Survey, Studies in Oklahoma's Past 16:101-104.

\section{END NOTES}

(1) Except for a few minor editorial changes, the text of this paper is exactly as I read it at the 35th Caddo Conference in Norman, Oklahoma. In the notes that follow I add some new information and I respond to some of the comments, particularly those of James Brown and Robert Brooks, that I received on the paper during and after the conference.

(2) Furthermore, as Helen Tanner reminded me in a conversation we had at the conference, there are no Caddoan traditions pertaining to an occupation of the Arkansas Valley or to Spiro. Considering that both Crenshaw and the Battle Mound are alluded to in versions of the Caddo origin myth (Swanton 1943:26-29) as the place where the Caddo people emerged from the underground world (one version puts "Chacanenah" at Hervey, Arkansas--the location of Crenshaw--but Chickaninny Prairie, the location of the Battle Mound, and Chacanenah are probably one and the same; see Hemmings 1982:61), it is reasonable to ask why a place as important as Spiro would have faded entirely from tribal memory. In a more generalized version of the myth presented by Mooney (1896:1093-1094) the Caddo appeared near the mouth of the Red River and moved up it to the west. There is no mention anywhere of another river to the north, or of a move to the south.

(3) It is now in print. See the bibliography for Schambach 1993.

(4) At the conference Brown seemed to be arguing that my claim that the Arkansas Valley tradition was not Caddoan is based upon an arbitrarily derived list of diagnostic Caddoan traits that I have concocted and that I use to remove from the Caddo area any region in which they do not appear. I do have a pretty good idea of what is and is not Caddoan, after 28 years in the field in the historically and ethnohistorically documented Caddo area in southwestern Arkansas, northwestern Louisiana, east- ern Texas and southeastern Oklahoma. But that is not the approach I am using because I know as well as Brown does that it leads in a circle. All I have done is unravel the historically and ethnographically undocumented Arkansas Valley tradition from the tradition that exists in the documented Caddoan area to the south, and then I have compared the two, taking into consideration population biology, epidemiology, diet, food preparation techniques, subsistence techniques, ceramic assemblages, tool assemblages, house types, mortuary patterns, mound construction techniques and culture history. The differences that have become apparent are, in my judgment, so numerous and so profound that, contrary to the conventional wisdom, and no matter what one calls them, two distinct populations and cultures must have been involved.

Anyone who thinks the Arkansas Valley should be called Caddoan despite these differences should explain why the whole Southeast shouldn't be called Caddoan.

(5) For example, Brown, Bell and Wyckoff (1978:194195) conclude their influential paper on "Caddoan" settlement patterns in the Arkansas Valley with two paragraphs wherein they recognize so many similarities between the Arkansas Valley tradition and the Middle Mississippian tradition that only a bit of obfuscation keeps these paragraphs from looking like the repudiation of the Northern Caddoan area paradigm that they actually are. They write: "As common and conventional as it is to consider the Caddoan cultural traditions separately from the Mississippian to the east, the one aspect [emphasis mine] in which it is more advantageous not to do so is in terms of subsistence-settlement patterns. The similar organization of communities around civicceremonial centers with platform mounds, combined with a basic agricultural technology based on hoe cultivation of maize, attests to the fundamental unity of the two areas.... Their essential continuity can be traced to a 
common economic base on the one hand and to the dominating influence of Mississippian ideology on the forms of Caddoan social integration on the other." In the next paragraph they go on to say "But at a more detailed level it is obvious that differences exist, which under closer scrutiny, can be shown to be the result of an advanced Mississippian subsistence-settlement system responding to a marginal environment for that system.

The significance of these paragraphs is obscured by the strikingly vague phrase: "the one aspect." An alert editor would have called for clarification by asking the authors the question they should have asked themselves: "the one aspect of what?" The answer is: "the one aspect of culture." Once they realized that, they would have been forced to revise their paragraphs, if not their entire paper, because the common elements they mention (subsistence base, horticultural techniques, economic base, settlement pattern, use of platform mounds, and ideology) add up to considerably more than one aspect of culture. They encompass, in one way or another, nearly the whole range of culture--which is why I keep insisting that the Arkansas Valley was not Caddoan.

(6) As Prewitt (1974:83-85) notes, the Arkansas Valley differs significantly from the Caddo area in climate, particularly rainfall and native vegetation. There is less rain in the Arkansas Valley in eastem Oklahoma and it is less predictable so corn horticulture would have been more difficult there than in the Red River Valley.

(7) When we come right down to it, the evidence--such as it is---upon which the Northern Caddoan Area paradigm rests consists of Caddoan pots in the Arkansas Valley and Middle Mississippian prestige goods in the Caddo area, both actually the work of Spiroan traders. As Story (1978:56-57) has observed, the boundaries of the Caddo area, as it was defined in the early years of Caddoan archeology, were based "in actual practice, primarily" on the distribution of Caddoan pots. In 1949 Krieger made it quite clear that this was the case, stating that the five geographical "foci" of his newly created early Caddoan "Gibson Aspect" (Spiro, Sanders, Alto, Haley and Gahagan) were "Primarily...bound together by a closely interrelated ceramic tradition..." (Newell and Krieger 1949:194; Fig 19, Fig. 62 and Map 1). He went on to say, citing his Cultural Complexes and Chronology in Northern Texas (1946:214-215): "...but important non-ceramic and burial traits also tie them together in diverse ways." Those who follow up his reference to see what traits he had in mind will discover that, except for a few traits like celts and small arrow points that are too widespread in the Southeast to carry much weight in comparisons of this kind, his list of artifacts or artifact types that co-occur in the Arkansas Valley and the Caddoan area amounts to what I would call a bill of lading for trade goods that were passing through the Sanders entrepot on their way to or from Spiro. "Some of the most important traits of this aspect," Krieger wrote (1946:215), "with the foci in which they occur most regularly are: effigy pipes of human and animal forms, made of beautifully polished stone and pottery (Spiro, Gahagan, Haley); long-stemmed pottery pipes with tiny, thin-walled bowl [sic] (all foci); large stone T-shaped pipes (Spiro, Gahagan); stone elbow pipes (Sanders, Spiro); stone ear spools (all foci); shell and wooden ear spools (Spiro, Haley, Sanders); ring shaped ear spools of pottery (Alto, Haley); use of copper on ear spools (all but Alto); copper covering on wooden beads (Spiro, Haley, Gahagan); plain conch-shell dippers (Spiro, Haley, Sanders); engraved conch-shell gorgets and "dippers" (Spiro, Sanders); repousse copper plaques (Spiro); copper masks with long noses, and hand effigies (Gahagan); pearl beads (Gahagan, Haley, Sanders) [The pearl beads found in the Red River Valley are imports. There are virtually no mussels in the Red River--certainly not enough to sustain a pearl fishery--due to its high salt and silt content]; Olivella beads (Sanders, Spiro); Marginella beads (Sanders); spatulate celts (all but Alto); flint blades with recurved edges and straight to concave base, of form known as "Copena Point" in Southeast (common in Spiro, Alto, and Gahagan; possibly occur in Haley); chipped and ground adzes or celts with flat sides and sharp polished bits (all foci): abrading stones of white Catahoula sandstone (all foci); small arrow points with serrated edges, slim, needlelike tip, flaring barbs, and bulb-shaped stem widest in the middle (all foci); sidenotched triangular arrow points (Gahagan). [At the 8th Caddo Conference Webb and Griffin agreed that these specimens from Gahagan-there were three, of a "white material"--are imports from Cahokia. Brown contributed the information that similar specimens were found in the Craig Mound at Spiro. See Davis, Wyckoff and Holmes 1971:56].

When it came to basic domestic and ceremonial traits, as opposed to small, transportable artifacts, Krieger could not point to any specific similarities between the Arkansas Valley and the Caddo area. What he actually notes, mostly, are differences between Spiro and Sanders, on the one hand, and the Red River Valley Caddoan sites on the other: "Sanders and Spiro burials were crowded into small graves, whereas those of Haley and Gahagan were placed parallel in rows in very large pits, usually with one or more skeletons laid at right angles to the main row and, and the grave offerings placed in piles against the pit walls" (1946:214). "Alto and Haley houses were circular and very large.... In no case has an entrance way other than one or more spaces between wall posts been discovered [that is no longer true, of course; see, for example, Webb 1959] nor has any definite arrangement of interior posts.... Spiro houses were square to rectangular, large and sturdily built with walls oriented along cardinal directions; they had two or four large central support posts, plastered floors, covered entranceway(sic) extending from one of the long sides,... Entranceway posts were set either individually or in trenches." (1946:214-215). Krieger listed burial mounds and temple mounds as common elements, which they are, broadly speaking, but we now know for a fact that the burial mounds and platform mounds of the Arkansas Valley are significantly different from those of the Caddo area (See above, this paper. See also, Bell 1972:259-260;1984:239 and Bell in Davis, Wyckoff and Holmes 1971:58-62). 
In a paper published since the conference, Kidder (1993; see also Perttula 1992:164) has finally removed from the Caddo area that other major spuriously Caddoan regional-temporal construct, the Glendora "focus." There too, James A. Ford's mistaken identification of the Keno and Glendora sites, and the whole Lower Ouachita Valley, as Caddoan was based on traded Caddoan pottery (Kidder 1993;233-234). Evidently the "thriving trade" in traditional ceramics for which the Natchitoches and other Red River Caddo groups were well known in the eighteenth century (Perttula 1992:168) had roots deep in the past.

The old Glendora material of the Ouachita Valley is now considered Tunican and/or Koroan (Perttula 1992:164). This is interesting considering that in 1952 Orr (1952:252) wrote: "Fort Coffee [ which we now know to be the domestic side of the Spiro and, I would say, Harlan phases] has ceramic similarities with Glendora, including swollen neck bottles and negative elements surrounded by hatchuring."

(8) Perhaps this commerce wasn't unparalleled. In a paper that appeared shortly after the Caddo conference, O'Brien (1993) has proposed that the Steed-Kisker phase people of the Kansas City area were acting as middlemen in a similar commerce between people of the Central Plains and Cahokia. In that paper she discusses the "universal" problem of documenting "invisible trade in foodstuffs and other perishable commodities" which is, I presume, the problem Brown was referring to when he criticized my interpretation of the Spiro phenomenon for relying too much on what he called "negative evidence." As O'Brien (1993:73) puts it: "Although we may lack concrete [archeological] evidence of trade in food and clothing ethnohistoric evidence documents their existence in the Southeast."

(9) Brown attacked my argument that the Spiroan phenomenon was based on the trading of fiber, fat and protein by stating that-- according to my notes and memory--: "If one reads the ethnographic literature, one finds that most people in North America were able to provision themselves." But were they? As Spielmann (1991b:1-2) points out, that has been the conventional wisdom. But during the last ten years it has been demonstrated that even the nonhierarchical societies of North America and elsewhere were "rarely self-sufficient with regard to subsistence and other basic material resources. In fact, such societies often engage in a wide variety of exchange relations in order to gain access to various material items." Among the North American peoples who were periodically or regularly exchanging "dietary supplements" or "dietary staples" (Spielmann 1986:Table 3) are the Netsilik/Inglulik, the Haida/Tlingit, the Chilkat Tlingit/Athabascans, the Nunamiut/Thremiut, the Southern Plateau tribes and the tribes of the Northern Plateau, Great Basin and Northwest Coast, the Yavapai/Yumans, the Huron/Algonkians, the various Plains horticulturalists and Plains hunter/gatherers and --most pertinent to the Spiro case-the Southern Plains hunter/gatherers and the Pueblo peoples. (For the latter see Creel 1991; Spielmann 1991a,b; Speth 1991; Baugh 1991.)

Furthermore, as Maynard Cliff pointed out to me after reading my latest paper on Spiro (Schambach 1993), Flannery (1968) has' constructed a model, based in part on the Chilkat Tlingit \Athabascan trading relationship noted above (see McClellan 1953), that in many ways matches and, I think, supports the one I proposed for the Spiroan phenomenon. As he puts it:

\begin{abstract}
"...data from several parts of the world suggest that a special relationship exists between consumers of exotic raw materials and their suppliers, especially when the suppliers belong to a society which is only slightly less stratified than that of the consumers. First, it seems that the upper echelon of each society often provides the entrepreneurs who facilitate the exchange. Second, the exchange is not "trade" in the sense that we use the term, but rather is set up through mechanisms of ritual visits, exchange of wives, "adoption" of members of one group by the other, and so on. Third, there may be an attempt on the part of the elite of the less sophisticated society to adopt the behavior, status trappings, religion, symbolism, or even language of the more sophisticated group--in short to absorb some of their charisma. Fourth, although the exchange system does not alter the basic subsistence pattern of either group, it may not be totally unrelated to subsistence. It may, for example, be a way of establishing reciprocal obligations between a group with an insecure food supply and one with a perennial surplus"(1968:105).
\end{abstract}

(10) Robert Brooks commented that by posing trade in bison products as the basis for the Spiro phenomenon, I am overemphasizing the importance of bison in the Arkansas Valley tradition. That does not surprise me because the idea that bison were unimportant until after the collapse of Spiro and the beginning of the Fort Coffee "focus" is one of the mainstays of the Northern Caddoan area paradigm (Schambach 1993:196-198). Arkansas Valley specialists must defend it or abandon the paradigm. All I need to say in response is that the evidence I present for bison usage during the Harlan and Spiro phases is the same evidence that they have traditionally accepted in support of idea that the people of the Fort Coffee "focus" were bison hunters par excellence. The only change is that it has now become apparent, due mainly to a radiocarbon dating project carried out by Rohrbaugh $(1982,1984)$, that the Fort Coffee "focus" was a spurious construct consisting mostly, if not entirely, of all the habitation sites of the Harlan and Spiro phases. For decades Arkansas Valley specialists have been systematically misclassifying these sites on the basis of the rule of thumb that all assemblages with bison bones, bison bone tools, bison processing tools and shell-tempered pottery were Fort Coffee "focus." In so doing they failed to notice, or wonder why, they were 
not finding Harlan and Spiro phase habitation sites (except Robert Bell; see below, the end of this note). Indeed they excluded from discussion--on the scientifically unacceptable grounds that they were anomalous-- the School Land I and School Land II sites, where abundant bison bones and shell-tempered pottery occur in apparent association with Harlan phase houses (which have Harlan phase radiocarbon dates) in small villages. These two sites produced osteological evidence that 26 to $47 \%$ of the meat consumed by Harlan phase people was bison (Duffield 1969: Tables I and V).

At this point, I doubt that it would be possible to overemphasize the importance of bison in Spiroan culture. I predict that good data from properly excavated sites will show that imported bison products were the mainstay of the Spiroan domestic economy and the Spiroan trade network from at least A.D. 1000 on.

To return to my point about Arkansas Valley specialists failing to notice or wonder about the absence of Harlan and Spiro phase habitation sites, Bell did notice and did wonder, but he went no farther. During a discussion session on the topic "Mounds, Architecture and Burials" at the Seventh Caddo Conference he said: "One other thing is bothering me a little bit. In the Spiro area or in the area around many of these ceremonial centers, where were all these people living that were contributing to and supporting these centers? If you look at the sites around the centers, they tend to be Fulton sites very often. For example, around Spiro, is it not a little peculiar that we get so many $\mathrm{Ft}$. Coffee [sites]? When you find a village around Spiro it is very likely to be Fulton." A little later, during the same discussion he said, in reference to the Harlan site: "You had the feeling that no one stayed there except a few priests that were kind of keeping things going. The people, presumably, must have lived up and down the river valley, and here and there you get the suggestion of a Gibson site. But I've been real puzzled about where some of these Gibson people were staying. I've been wondering if some of the material we're calling Fulton may not be representative of this." (In Davis, Wyckoff, and Holmes 1971:55-56).

(11) Dee Ann Story (1991:17) notes that "the oft-cited analysis of the Sanders site (Krieger 1946:172-218) is preliminary and does not separate all components now identifiable in the artifact collection at TARL. Furthermore, the excavations at Sanders left much of the site unsampled."

(12) The trade route would have been essentially the same as the old railroad route from Spiro, Oklahoma to Paris, Texas, i.e., the route of the Kansas City-Southern line from Spiro to Poteau, Oklahoma and then the route of the St. Louis-San Francisco line from Poteau (via what appears on topographic maps to be a natural gorge through Winding Stair Mountain) southwest to Antlers, Oklahoma and then south to Paris, Texas. The route from Spiro to Antlers is so constricted by various river valleys and mountain passes, and so obviously the easiest and most logical route that it should be possible to find some of the way-stations the Spiroan porteurs must have used.

(13) As James Brown pointed out at the conference, there may be a Woodland component at Sanders. What I should have said here is "the complete Mississippi period assemblage."

(14) Judging from the paper Diane Wilson presented just before mine at the conference ["Incidence of Degenerative Joint Disease Among the Sanders Site (41LR2) Population"] I should probably change this to "backs and heads." As I recall, she reported that one of the peculiarities of the Sanders site skeletal population was it looked as if those people had spent a lot of time carrying loads on their heads. That observation did not surprise me.

(15) Since I read this paper at the conference, I have learned that according to various authorities the native distribution of Osage orange, or bois d'arc (Maclura pomifera), probably comprised a phenomenally small area in extreme southeastern Oklahoma, extreme southwestern Arkansas, and eastern Texas (Sargent 1955:33; Smith and Perino 1981:Figure 2; Harrar and Harrar 1962:257-259; Preston 1989:232-233; and Petrides 1972:191-192). It has since been planted widely as hedgerow by Europeans. The most conservative versions of the Osage orange distribution map (Preston 1989:232; Smith and Perino 1981:Figure 2,b) depict a native range with its northern limit in the Red River Valley between Fulton in southwest Arkansas and Durant, Oklahoma and Bonham, Texas. From there it trails off to the southwest in a ninety to one hundred mile wide band that ends in the vicinity of San Antonio. Thus it is possible, if not probable, that Osage orange did not grow north of the Red River Valley, or outside of the territory of the Red River Valley and east Texas Caddos. This would have given them a monopoly on the best and most desired bow wood in North America other than the Pacific yew. Whatever its source, we know that in early historic times it was traded as far north as the Blackfoot country in Montana, possibly as far northeast as headwaters of the Mississippi, as far west as the Pueblos, as far southwest as Sonora, Mexico (Pope 1962:14-15), and at least as far east as the mouth of the Arkansas (Mason 1972:10; Peattie 1953:480; Hamm 1989:21-22; Hamm 1989:17; Robbins, Harrington and Freire-Marreco 1916:68; Swanton 1942:37,192, 238; Swanton 1942:192). It was used extensively in the central and southern Plains (Hamm 1989:17-22). The Sanders site is located in the middle of the northern end of this (putative) limited range, suggesting to me that the main items carried up the Kiamichi to Spiro and from there to points east and west were Osage orange bows or bow staves of Caddoan manufacture.

Even if Osage orange happened to grow a significant distance north of the Red River Valley as some distribution maps indicate, such trees might not have been suitable for bow making (Smith and Perino 1981:Figures $2 a, c, d)$. Although the tree is very adaptable, it prefers deep, rich river bottom soils (Smith and Perino 1981:29). 
Trees grown in such soils are straight grained compared to trees grown in the uplands which tend to have twisted grain patterns. Modern bowyers claim that only straight grained trees grown in river bottom soils are suitable for bows (Waldorf 1985: 5).

The trade in Osage orange bows that Swanton postulated for the Hasinai in the sixteenth century, and for which the Kadohadacho were famous in the seventeenth century probably had roots deep in the prehistoric past (Swanton 1942:192-193). We know from prehistoric specimens from burials at the Mounds Plantation site in northwestern Louisiana and the Bowman site in southwestern Arkansas the Caddo were using Osage orange bows by A.D. 1050 (Webb 1984:18). There are fragments of Osage orange bows in the Chance and Spencer collections from this site.

(16) This effigy is from the McLemore site in central Oklahoma (Pillaert 1963: Plate XVI). As Dan Morse informed me, it is typical of the specimens that Phillips, Ford and Griffin (1951:167; Table 4:196) referred to as "man-bowls" or "Chacmool" effigies. These are most common in the Cumberland area but they also occur in northeastern Arkansas and southeastern Missouri and there are specimens from Moundville and from southwestern Indiana.

The bowl was not the only import at the site. Pillaert (1963:42) lists as additional evidence that "the people of the McLemore site were in contact with alien populations with whom they traded and borrowed ideas"... "flint from native quarries in Texas and north central Oklahoma, marine conch-shells from the Gulf of Mexico and steatite whose most likely source would have been Cherokee County, South Carolina." There was also an Olivella shell that could have come from the Gulf Coast or the Pacific Coast.

(17) Jenna Kuttruff's article (1993) on "Caddoan"--the Northern Caddoan area paradigm continues to obfuscate-textiles from Spiro and the Ozarks appeared after I read this paper. Kathy Cande noticed and pointed out to me Kuttruff's observations about red cloth at Spiro, which are as follows: "Unlike the colors of yellow and brown, the number of possible sources of red dye is limited in North America.... and its use may have been restricted to individuals of higher status. Madder (most likely a species of Galium or bedstraw) and cochineal (Dactylopius coccus) are the principal sources of red dye in this area. Madder, which has been identified in at least one example of Spiro textiles..., would have been available in the southeastern United States, but cochineal would probably have required importation from the American Southwest or from Mexico" (Kuttruff 1993:140). This certainly doesn't mean that Spiroan traders were importing cochineal or cochineal dyed cloth from the Southwest, but it is an interesting possibility. And what about the madder dyed cloth? Given the apparent scarcity of red cloth in archeological contexts from eastern North America, would it be more reasonable to assume that it was made locally, or that it was imported?
(18) In a recent paper in which she interprets the Steed-Kisker phase in much the same way I am interpreting Spiro, i.e., as middlemen in a vast trade network that involved Mississippian villagers to the east of them and Plains buffalo hunters to the west of them, O'Brien (1993: 74,78 ) notes the trade of a "slave girl" on the Plains in the historic period and makes the interesting suggestion that "Given the levels of human sacrifice practiced at Cahokia, slaves may also have moved through this network...". See also her map (Fig. 11) showing a trail system that linked Spiro with Cahokia.

(19) I did not read this part of the paper at the conference, due to lack of time. I include it here, as it was written, because the Nagle site figured prominently in the discussion that followed my paper.

(20) Brooks stated that physical anthropologist Douglas Owlsley's reexamination of the Nagle site skeletal population indicated the people buried at Nagle were "starving to death" (his exact words, according to my notes), a condition that he (Brooks) did not believe to be consistent with my hypothesis that they were traders from Spiro occupying what would presumably have been a well established Plains entrepot. I doubt that the forthcoming report by Owlsley that Brooks referred to will contain that diagnosis because death by starvation is not something that can be determined from skeletons. It happens too quickly to register in the bones. Owlsley may have found that under $\mathrm{X}$ ray examination the bones show "Harris lines," which are indicators of periods of dietary stress during childhood. These are quite common in American Indian skeletons. They reflect seasonal shortages, generally during the Spring, when stored foods were running out and new supplies were not yet available. People generally survived these lean times but they were registered in the bones of growing children (who need more protein than adults) as periods of interrupted growth.

In the paper from which this one was drawn (Schambach 1993:207), I cite some of Owlsley's recently published observations on the Nagle site skeletons. They represent (he writes, in Owlsley and Jantz 1989:140 and Owlsley 1989:131) a population with "a totally different set of health problems" than those exhibited by populations from other Central Plains sites, namely "a severe mortality profile, associated with pronounced evidence of bone disease." These conditions, he notes, are indicative of dietary deficiencies, possibly scurvy, and a syphilis-like bone disease. As Alice Brues (1957) pointed out in her original report on these skeletons, the scurvy was probably due, not to starvation, but to certain small deviations from the normal Plains Villager diet such as eating liver cooked rather than raw, or failing to include enough squash in a diet based on vitamin C deficient foods such as com, bison meat and tallow. These small but, for some, serious and perhaps sometimes fatal, errors strike me as exactly the kinds of mistakes a group of Spiroan traders from eastern Oklahoma might have made while trying to maintain a trading post in an unfamiliar environment with unfamiliar foods. 
(21) Brooks said he thinks the Nagle site people were not traders but "refugees" from eastern Oklahoma, although he didn't say what event or situation they were fleeing in eastern Oklahoma at the time (A.D. 1300 1390 ) he mentioned. I think it would be difficult to construct an archeologically and ethnographically plausible scenario based on that idea, particularly if one works within the parameters of the Northern Caddoan Area paradigm. The difficulty would lie in getting around one of its major premises: that there was no contact between Spiroan people and Plains people until the middle of the fifteenth century. Assuming that some acceptable reason could be adduced for the exodus that Brooks proposes (was it a mass movement or was it just the group represented by the sixteen skeletons at Nagle?), why would Fourteenth Century Spiroans (there seems to be no doubt that they were Spiroans) have decided to flee west into unknown territory? Since they were supposedly Caddoans, why didn't they move south to take refuge with other Caddoans?
There are lots of things in archeology that can't be explained but the Nagle site isn't one of them. All that is needed is the right paradigm. While the Nagle site makes no sense as a place where Spiroan refugees, fleeing blindly into the wilderness for no discernible reason, finally went to ground, it would have been a good base for Spiroan traders interested in dealing with the Washita River phase people of central Oklahoma. This would account for the "true trade ware" (Brooks 1987:97-98) pots of Spiro Engraved or Hickory Engraved, and perhaps Sanders Plain, that reached central Oklahoma Washita River phase sites like the Arthur site about the time the Nagle site burials were emplaced. It would also explain the cut shell beads (I doubt that these were made locally; I think they came from a Central Mississippi Valley bead factory) and the Mississippian human effigy bowl, the latter from the Tennessee-Cumberland area (Pillaert 1963: Plate XVI; Bell 1984:322) from the McLemore site. How would the "refugee hypothesis" account for the occurrence of these Caddoan and Mississippian specimens so far from home in west central Oklahoma?

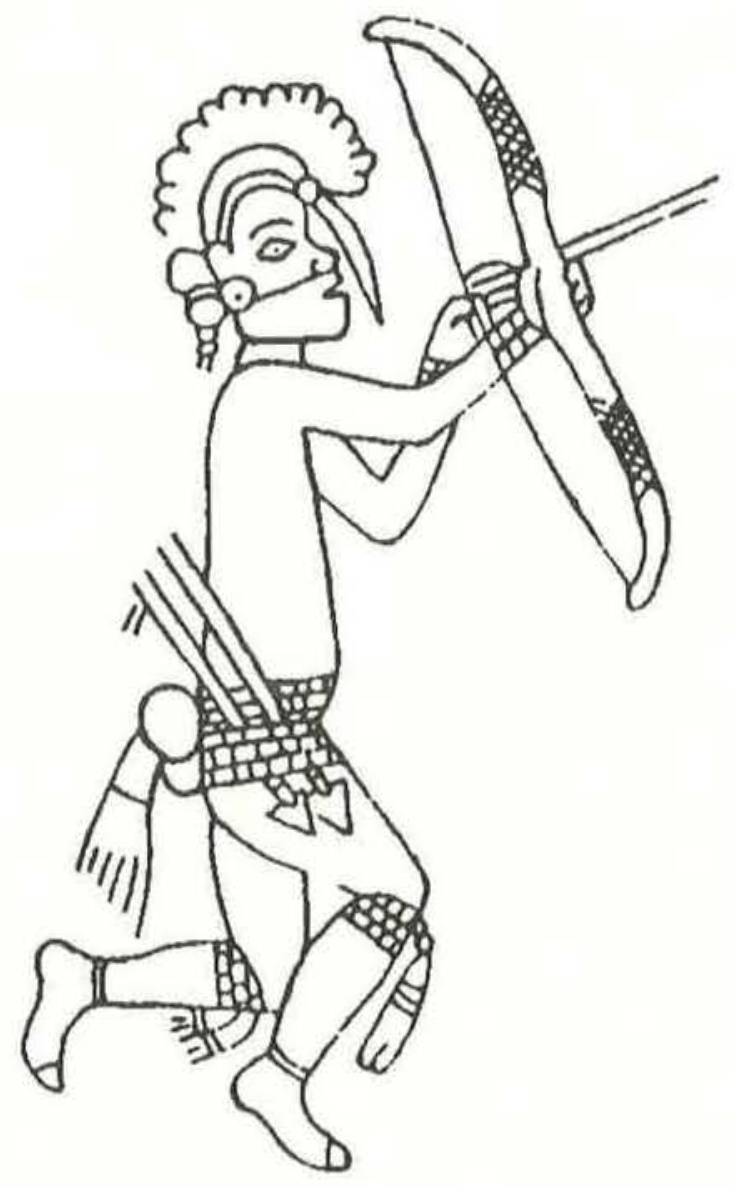

